Joeliatin. Hubungan Tingkat Pendidikan Suami Pasangan Usia Subur Dengan Minat Suami Mengikuti Metode Operatif Pria (MOP) Di Wilayah Kerja Puskesmas Kertosono Kabupaten Nganjuk Tahun 2018

\title{
HUBUNGAN TINGKAT PENDIDIKAN SUAMI PASANGAN USIA SUBUR DENGAN MINAT SUAMI MENGIKUTI METODE OPERATIF PRIA (MOP) DI WILAYAH KERJA PUSKESMAS KERTOSONO KABUPATEN NGANJUK TAHUN 2018
}

\author{
Joeliatin \\ Akademi Kebidanan Wiyata Mitra Husada Nganjuk \\ Email : yulisuyitno77@gmail.com
}

\section{ABSTRAK}

Metode operasi metode sterilisasi pria adalah dengan cara mengikat saluran sperma (vas deferens) pria. Yang memakai MOP adalah 0,25\%, ini menunjukkan bahwa partisipasi suami dalam mengikuti MOP masih sangat kecil. Tujuan dalam penelitian ini adalah untuk mengetahui tingkat pendidikan Hubungan suami Pasangan Usia subur dengan minat suami mengikuti MOP.

Penelitian ini merupakan penelitian analitik yang bersifat Cross Sectional. Sampel diambil dengan teknik Simple Random Sampling dari Pasangan Suami Istri Subur 524 diperoleh sampel sebanyak 84 responden. Cara menggunakan pengumpulan data formulir pertanyaan dengan cara melakukan penelitian di pintu ke pintu. Analisis data dalam penelitian ini yaitu menggunakan uji Chi Square.

Hasil penelitian ini menunjukkan bahwa semakin tinggi tingkat pendidikan pasangan Suami Usia subur maka semakin tinggi minat untuk menggunakan MOP. Hasil tes SPSS menunjukkan bahwa nilai $\mathrm{p}<\alpha(0,05)$ yang merupakan persyaratan penolakan $\mathrm{H} 0$ dan $\mathrm{H} 1$ diterima. Jadi ada pendidikan tingkat tertinggi suami Pasangan Usia subur dengan minat suami mengikuti MOP.

Maka dapat disimpulkan bahwa ada hubungan antara tingkat pendidikan suami dengan Pasangan Usia Subur dengan minat suami mengikuti Metode Operatif untuk pria. Saran komunitas diharapkan semakin menambah pengetahuan tentang kontrasepsi pel terutama pasangan usia subur kepada suami.

Kata Kunci : Tingkat Pendidikan, MOP, Minat

\section{ABSTRACT}

Operative methods of sterilization method man is by way of binding the sperm ducts (vas deferens) men. Who wears a MOP is $0.25 \%$, this indicates that the husband's participation in following the MOP is still very small. The goal in this research is to know the level of Relationship education husband Spouse Age lush with interest the husband follows the MOP.

This research is research that is both analytical Cross Sectional. Samples taken with the technique of Simple Random Sampling of Fertile Age Spouse husband 524 obtained a sample of 84 respondents. How to use the question form data collection by way of doing research in door to door. Data analysis in this study i.e. using test Chi Square.

The results of this study showed that the higher the educational level the fertile Age Spouse husband then the higher interest to use the MOP. SPSS test results showed that $p$ value $<\alpha(0.05)$ which is a requirement of rejection of $\mathrm{HO}$ and $\mathrm{H} 1$ are accepted. So there is the highest-level education husband Spouse Age lush with interest the husband follows the MOP.

Then it can be inferred that there is a relationship between the level of education of fertile Age Spouse husband with husband's interest following the Operative Methods for men. Advice community is expected to further increase knowledge about contraception MOP especially Fertile Age Couples to the husband.

Keywords : Educational Level, MOP, Interests 


\section{PENDAHULUAN}

Menurut World Health Organitation

(WHO) keluarga berencana adalah tindakan yang membantu pasangan suami istri untuk menghindari kehamilan yang tidak diinginkan,mendapatkan kelahiran yang memang sangat di inginkan, mengatur interval diantara kehamilan, mengontrol waktu saat kelahiran dalam hubungan dengan umur suami istri serta menentukan jumlah anak dalam keluarga. Metode Operatif Pria merupakan kontap (vasektomi) dengan jalan memotong vas deferens sehingga saat ejakulasi tidak terdapat spermatozoa dalam cairan sperma. Setelah menjalani vasektomi tidak segera akan steril, tetapi memerlukan sekitar dua belas kali ejakulasi, baru sama sekali bebas dari spermatozoa. Oleh karena itu diperlukan penggunaan kondom selama dua belas kali ejakulasi sehingga bebas untuk melakukan

Hubungan seks Secara global prevalensi kontrasepsi (contraceptive prevalence) pada tahun 2006 - 2012 mencapai $63 \%$. Di wilayah Asia sebesar 59\% (Anonim, 2014 : 114). Data Badan Kependudukan dan Keluarga Berencana Nasional (BKKBN) menunjukkan bahwa pada tahun 2013 ada 8.500.247 PUS (pasangan usia subur) yang merupakan peserta KB baru. Yang memakai MOP $0,25 \%$. Ini menunjukkan bahwa partisipasi laki-laki dalam menggunakan alat kontrasepsi masih sangat kecil, apalagi kontrasepsi jenis MOP. Data BKKBN menunjukkan bahwa pada tahun 2013 MOP merupakan metode kontrasepsi pria yang digunakan oleh peserta KB baru pasca persalinan / keguguran sebanyak 0,07\% (Anonim, 2014 : 5).Pada tahun 2008data di Provinsi Jawa Timur jumlah PUS sebesar 5.826.910 jiwa,yang mamakai alat kontrasepsi KB priadisebut MOP 0,35\% (Anonim, 2009: 23).

Studi pendahuluan di Kecamatan Kertosono bulan Pebruari 2016 menunjukkan bahwa di Kecamatan Kertosono Jumlah Pasangan Usia Subur adalah 525 orang $(5,5 \%)$ dari jumlah PUS tersebut yang menggunakan kontrasepsi MOP adalah 84 orang (0,5\%). Masyarakat selama ini masih belum mendapatkan pengetahuan KB secara utuh.Selama ini masih banyak orang yang tidak mengetahui kenapa dirinya memilih jenis kontrasepsi tersebut.Kebanyakan orang memilih alat kontrasepsi itu karena tetangga atau memang hanya mengetahui satu jenis kontrasepsi saja. Pada Metode Operatif Pria (MOP) merupakan salah satu metode kontrasepsi yang dilakukan melalui operasi kecil pemotongan atau pengikatan saluran sperma. Pada metode ini, juga sangat diperlukan adanya konseling dan informed consent (persetujuan) karena bersifat permanen. Dalam konseling tersebut harus dijelaskan juga bagaimana teknik operasi dan kemungkinan penyulit yang bias terjadi setelah operasi, karena orang masih menganggap operasi adalah suatu hal yang sangat menakutkan (Proverawati, 2013: 44).

Hal ini disebabkan bahwa pemilihan kontrasepsi secara rasional masih belum tersosialisasi dengan baik karena proses informed choise dan konseling belum dilaksanakan (Azis, 2014: 22).

Adapun faktor-faktor yang mempengaruhi kurangnya tingkat pendidikan suami pasangan usia subur tentang MOP adalah dari faktor sosial ekonomi, budaya, pengetahuan, agama dan dukungan istri. Untuk meningkatkan minat laki-laki pasangan usia subur untuk berpartisipasi mengikuti program KB MOP dengan cara pengadaan penyuluhan tentang pentingnya peran laki-laki dalam mengikuti program $\mathrm{KB}$, penyuluhan yang diberikan kepada pasangan usia subur yaitu bahwa laki-laki juga dapat berperan dalam program KB (Hartanto, 2013: 22).

Untuk itu sebaiknya informasi tentang alat kontrasepsi tidak ada yang 
Joeliatin. Hubungan Tingkat Pendidikan Suami Pasangan Usia Subur Dengan Minat Suami Mengikuti Metode Operatif Pria (MOP) Di Wilayah Kerja Puskesmas Kertosono Kabupaten Nganjuk Tahun 2018

disembunyikan baik dari segi keuntungannya, bagaimana prosedur penggunaannya, dan apa saja yang berkaitan dengan kontrasepsi tersebut karena tingkat pendidikan merupakan faktor yang sangat penting untuk terbentuknya suatu minat. Dengan tingkat pendidikan yang memadai maka akan timbul minat untuk memilih kontrasepsi Metode Operatif Pria (MOP), maka kemungkinan besar masyarakat khususnya Pasangan Usia Subur (PUS) akan memilih metode kontrasepsi yang paling efektif diantara metode-metode yang lain.

\section{Tujuan Penelitian}

Untuk mengetahui Hubungan Tingkat Pendidikan Suami Pasangan Usia Subur Dengan Minat Suami Mengikuti Metode Operatif Pria Di Wilayah Kerja Puskesmas Kertosono Kabupaten Nganjuk Tahun 2016.

\section{METODE PENELITIAN}

Jenis penelitian yang digunakan adalah analitik korelasional yaitu penelitian yang bermaksud mencari hubungan antara dua variabel dengan menggunakan teknik analisa tertentu pada situasi atau kelompok subyek (Notoadmodjo, 2010:137). Peneliti memilih jenis penelitian ini karena bertujuan untuk menganalisa hubungan tingkat pendidikan suami pasangan usia subur dengan minat suami pasangan usia subur dalam mengikuti KB MOP di wilayah kerja puskesmas Kertosono Tahun 2016.

HASIL PENELITIAN DAN PEMBAHASAN

Tabel 4.1: Distribusi Frekuensi Responden Berdasarkan Umur di Wilayah KerjaPuskesmas Kertosono Kabupaten Nganjuk Tahun 2016

\begin{tabular}{cccc}
\hline No & Umur & Jumlah & Presentase \\
\hline 1. & $\begin{array}{c}>20 \\
\text { tahun }\end{array}$ & 0 & $0 \%$ \\
\hline 2. & $\begin{array}{c}20-35 \\
\text { tahun }\end{array}$ & 35 & $41,7 \%$ \\
\hline
\end{tabular}

\begin{tabular}{ccc}
\hline 3. & $>35$ \\
$\begin{array}{c}\text { tahun } \\
\text { TOTAL }\end{array}$ & 49 & $58,3 \%$ \\
\hline TOTA & 84 & $100 \%$ \\
\hline
\end{tabular}

Sumber: Data primer, 2016

Berdasarkan Tabel 4.1 dapat diinterprestasikan bahwa sebagian besar responden berusia $>35$ tahun sejumlah 49 responden $(58,3 \%)$ dan hampir setengah responden berumur 20-35 tahun (41,7\%) dan tidak satupun yang berumur $<20$ tahun.

Tabel 4.3: Distribusi Frekuensi Responden Berdasarkan tingkat Pendidikan di Wilayah Kerja Puskesmas Kertosono Kabupaten Nganjuk Tahun 2016

\begin{tabular}{cccc}
\hline No & $\begin{array}{c}\text { Tingkat } \\
\text { Pendidikan }\end{array}$ & Jumlah & Presentase \\
\hline 1. & $\begin{array}{c}\text { Dasar (SD, } \\
\text { SMP/SLTP) }\end{array}$ & 73 & $87 \%$ \\
\hline 2. & $\begin{array}{c}\text { Menengah } \\
\text { (SMA/SLTA) }\end{array}$ & 10 & $12 \%$ \\
\hline 3. & $\begin{array}{c}\text { Tinggi } \\
\text { (Akademi, } \\
\text { Perguruan } \\
\text { Tinggi) }\end{array}$ & 1 & $1 \%$ \\
& & \\
\hline & Total & 84 & $100 \%$ \\
\hline
\end{tabular}

Sumber: Data primer, 2016

Berdasarkan Tabel 4.3 dapat diinterprestasikan bahwa hampir seluruh responden dengan tingkat pendidikan dasar (SD, SMP/SLTP) sejumlah 73 responden $(87 \%)$, sebagian kecil tingkat pendidikan menengah yaitu 10 responden (12\%) dan sebagian kecil dengan tingkat pendidikan tinggi 1 responden (1\%).

Tabel 4.4: $\quad$ Distribusi Frekuensi Minat Mengikuti Metode Operatif Pria (MOP) Di Wilayah Kerja Puskesmas Kertosono Kabupaten Nganjuk Tahun 2016

\begin{tabular}{lccc}
\hline No & Minat & Jumlah & Presentase \\
\hline 1. & Minat & 60 & $71,4 \%$ \\
& Rendah & & \\
& $(0-33 \%)$ & & \\
\hline
\end{tabular}


Joeliatin. Hubungan Tingkat Pendidikan Suami Pasangan Usia Subur Dengan Minat Suami Mengikuti Metode Operatif Pria (MOP) Di Wilayah Kerja Puskesmas Kertosono Kabupaten Nganjuk Tahun 2018

\begin{tabular}{cccc}
\hline 2. & Minat & 20 & $23,8 \%$ \\
& Sedang & & \\
& $(34-$ & & \\
& $66 \%)$ & & \\
\hline 3. & Minat & 4 & $4,8 \%$ \\
& Tinggi & & \\
& $(67-$ & & \\
& $100 \%)$ & & \\
\hline & Total & 84 & $100 \%$ \\
\hline
\end{tabular}

Sumber: Data Primer, 2016

Berdasarkan Tabel 4.4 dapat diinterprestasikan bahwa sebagian besar responden memiliki minat rendah (0-33\%) mengikuti Metode Operatif Pria yaitu sejumlah 60 responden $(71,4 \%)$, sebagian kecil responden minat sedang (34-66\%) yaitu sejumlah 20 responden $(23,8 \%)$ dan sebagian kecil responden minat tinggi yaitu sejumlah 4 responden $(4,8 \%)$.

\section{Hasil Uji Chi-Square}

Tabel 4.6 Uji Chi Square Hubungan Tingkat Pendidikan Suami Pasangan Usia Subur Dengan Minat Suami Mengikuti Metode Operatif Pria Di Wilayah Kerja Puskesmas Kertosono Kabupaten Nganjuk Tahun 2016

\begin{tabular}{lccr}
\hline & Value & df & $\begin{array}{r}\text { Asymp. } \\
\text { Sig. (2- } \\
\text { sided) }\end{array}$ \\
\hline $\begin{array}{l}\text { Pearson } \\
\text { Chi-Square }\end{array}$ & $66.842^{\mathrm{a}}$ & 4 & .000 \\
\hline $\begin{array}{l}\text { Likelihood } \\
\text { Ratio }\end{array}$ & 40.717 & 4 & .000 \\
\hline $\begin{array}{l}\text { Fisher's } \\
\text { Exact Test }\end{array}$ & 37.668 & & \\
\hline $\begin{array}{l}\text { Linear-by- } \\
\text { Linear } \\
\text { Association }\end{array}$ & $6.416^{\mathrm{b}}$ & 1 & .011 \\
\hline $\mathrm{N}$ of Valid & & & \\
Cases & & & \\
\hline
\end{tabular}

a. 5 cells $(55.6 \%)$ have expected count less than 5 . The minimum expected count is .10 . b. The standardized statistic is -2.533 .

Berdasarkan hasil analisa menggunakan uji statistik Chi Square dengan program SPSS for Windows 8 versi 21, dapat dilihat dari Pearson Chi Square dan Asymp Sig(2-sided) yaitu 0,000 dengan demikian $p$ value $<a(0,05)$ yaitu $0,000<$ 0,05 yang artinya $\mathrm{H}_{0}$ ditolak. Maka dapat disimpulkan bahwa ada hubungan antara tingkat pendidikan suami Pasangan Usia Subur dengan Minat Suami Mengikuti Metode Operatif Pria di wilayah Kerja Puskesmas Kertosono Kabupaten Nganjuk Tahun 2016.

\section{PEMBAHASAN}

Berdasarkan hasil penelitian yang telah dilakukan pada suami pasangan usia subur di wilayah kerja Puskesmas Kertosono dengan jumlah sampel 84 responden, didapatkan data bahwa sebagian besar umur responden adalah $>35$ tahun yaitu sebanyak 49 responden $(58,3 \%)$, sedangkan responden yang berumur 20-35 tahun yaitu sebanyak 35 responden $(41,7 \%)$.

Menurut Elisabeth dalam Nursalam (2013: 45) usia adalah umur individu yang terhitung mulai saat dilahirkan sampai berulang tahun terakhir. Sedangkan Hurlock (1998) semakin cukup umur, tingkat kematangan dan ketekunan seseorang akan lebih matang dalam berfikir dan bekerja. Dari segi kepercayaan masyarakat seseorang yang lebih dewasa dipercaya dari orang yang belum tinggi kedewasaannya. Hal ini sebagai bagian dari pengalaman dan kematangan jiwa (Wawan, 2010: 17).

Dari penelitian ini didapatkan bahwa dari 84 responden didapatkan sebagian besar responden dengan pendidikan dasar yaitu sejumlah 73 responden (87\%), pendidikan menengah 10 responden (12\%), pendidikan tinggi 1 responden (1\%).

Menurut Tirtarahardja (2010: 37) disebutkan fungsi dan tujuan pendidikan 
yaitu menanamkan tingkah laku dan kebiasaan. Sedangkan faktor-faktor yang mempengaruhi pendidikan motivasi dari lingkungan sekitar termasuk guru, orang tua dan lingkungan, faktor lingkungan sekitar yang mempengaruhi konsentrasi.

Semakin tinggi tingkat pendidikan suami Pasangan Usia Subur maka suami semakin mudah dalam menerima informasi dengan baik pendidikan juga sangat mempengaruhi dalam pemilihan kontrasepsi yang akan digunakan untuk pasangan suami istri, dalam hal itulah maka pasangan suami istri memilih menggunakan kontrasepsi yang di kiranya sangat efektif dan efek sampingnya sangat minim sekali. Dari sinilah pola pikir dan daya tangkap suami tentang informasi yang masuk mungkin berbeda-beda, suami yang memiliki pola pikir yang baik mungkin lebih bisa menerima informasi yang didapatkannya, sedangkan suami yang memiliki pola pikir yang misalnya saja rendah belum tentu dapat menerima serta menyerap apa yang di informasikan. Maka dari itu informasi yang masuk harus sesuai dengan kenyataannya agar tidak terjadi kesalah pahaman dan salah persepsi mengenai kontrasepsi.

Dari penelitian ini didapatkan data bahwa dari 84 responden dalam penelitian yang dilakukan di Wilayah Kerja Puskesmas Kertosono, sebagian besar dari responden yang merupaka suami Pasangan Usia Subur memiliki minat rendah untuk mengikuti Metode Operatif Pria, yaitu sejumlah 60 responden $(71,4 \%)$, memiliki minat sedang yaitu sejumlah 20 responden $(23,8 \%)$, minat tinggi sejumlah 4 responden $(4,8 \%)$.

Minat merupakan sumber motivasi yang mendorong orang untuk melakukan apa yang mereka inginkan bila mereka bebas memilih. Ketika seseorang menilai bahwa sesuatu akan bermanfaat, maka akan menjadi berminat, kemudian hal tersebut akan mendatangkan kepuasan.
Dalam penelitian ini sebagian responden kurang berminat dalam menggunakan Metode Operatif Pria. Minat para responden tersebut dipengaruhi oleh beberapa faktor yaitu faktor tingkat pendidikan, faktor pengetahuan, faktor agama, faktor sosial budaya sehingga kemungkinan seiring berjalannya waktu minat tersebut dapat berubah.

\section{KESIMPULAN}

Berdasarkan hasil analisis dan pembahasan dalam penelitian ini dapat disimpulkan bahwa : Dari 84 responden yang merupakan suami Pasangan Usia Subur didapatkan data bahwa sebagian besar responden memiliki tingkat pendidikan Dasar yaitu sejumlah 73 responden $(87 \%)$, responden dengan pendidikan menengah yaitu sejumlah 10 responden (12\%), dan yang berpendidikan tinggi yaitu sejumlah 1 responden (1\%), Dari 84 responden yang merupakan suami Pasangan Usia Subur didapatkan data bahwa sebagian besar responden kurang berminat menggunakan Metode Operatif Pria yaitu sejumlah 60 responden $(71,4 \%)$, sisanya yaitu responden yang cukup berminat yaitu sejumlah 20 responden $(23,8 \%)$, dan 4 responden $(4,8 \%)$ sangat berminat menggunakan Metode operatif Pria.

Berdasarkan hasil analisa menggunakan uji statistik Chi Square dengan program SPSS for Windows 8 versi 21, dapat dilihat dari pearson Chi Square dan Asymp Sig (2-sided) yaitu 0,000 dengan demikian $p$ value $<$ a $(0,05)$ yaitu $0,000<0,05$ yang artinya $\mathrm{H}_{0}$ ditolak. Maka dapat disimpulkan bahwa ada hubungan antara tingkat pendidikan suami Pasangan Usia Subur dengan Minat Suami Mengikuti Metode Operatif Pria di wilayah Kerja Puskesmas Kertosono Kabupaten Nganjuk Tahun 2016.

\section{SARAN}


Joeliatin. Hubungan Tingkat Pendidikan Suami Pasangan Usia Subur Dengan Minat Suami Mengikuti Metode Operatif Pria (MOP) Di Wilayah Kerja Puskesmas Kertosono Kabupaten Nganjuk Tahun 2018

Saran bagi penelitian selanjutnya diharapkan dapat mengembangkan variabel penelitian dan menambah jumlah sampel sehingga didapatkan hasil yang lebih baik.

\section{DAFTAR PUSTAKA}

Anonim, 2012. Undang-Undang Sisdiknas Sistem Pendidikan Nasional, Bandung: Fokusmedis. , 2013. "KTI dan Sripsi". (Depkes, 2013: 33).

,2013. "Laporan Hasil Pelayanan Kontrasepsi" http://www.bkkbn.go.id. Diakses 10 Desember 2015).

Anggrain, 2012. Pengantar Minat dan Sikap Manusia. Jakarta: Sinar Harapan.

Azis, 2014. Pemasangan dan Panduan Keluarga Berencana. Jakarta: Salemba Medika.

Glasier, Anna, 2013. "Keluarga Berencana dan Kesehatan Reproduksi". Jakarta: Buku Kedokteran EGC.

Hartanto, Hanafi. 2013. "Keluarga Berencana dan Kontrasepsi". Jakarta: Pustaka Sinar Harapan.
Hidayat, A, Aziz Alimul. 2010, Metode Penelitian Kebidanan Dan Teknik Analisa Data. Jakarta: Salemba Medika.

Manuaba, Fajar. 2013. "IImu Kebidanan Penyakit Kandungan dan Keluarga Berencana Untuk Pendidikan Bidan. Jakarta: Buku Kedoteran EGC.

Notoatmodjo, Prof. Dr. Soekidjo, 2010. Promosi Kesehatan dan IImu Perilaku, Jakarta: Rineka Cipta.

Nursalam, 2010. Konsep dan Penerapan Metodologi Penelitian IImu Keperawatan, Edisi 2, Jakarta: Salemba Medika.

Proverawati, Atikah dan Andhini. D. S. C. 2013. Keluarga Berencana. Yogyakarta: Nuha Medika.

Sarwono, 2011, Buku Panduan Praktis Pelayanan Kontrasepsi, Jakarta: Bakti Husada.

Sugiyono, 2010, Metode Penelitian Pendidikan Pendekatan Kuantitatif, Kualitatif dan R\&B. Bandung: Alfebeta.

Tirtarahardja, 2008, Pengantar Pendidikan. Yogyakarta: Rineka Cipta. 